\title{
LEGAL LIMITATIONS IN THE PRACTICE OF THE PRIMARY HEALTH CARE NURSE
}

\author{
$\mathrm{J}$ Bierman and $\mathrm{M}$ Muller
}

\begin{abstract}
In this article the legal limitations in the practice of the primary health care nurse in the Republic of South Africa, having direct implications for the achievement of the goal: "Health for all by the year 2000", are explored and described The questions which had to be answered by means of the research are in relation to the nature and scope of the limitations obstructing the practice of the primary health care nurse. A legislative (document) analysis was performed and limitations in the legislation confirmed. It is recommended that an empirical investigation be done to verify the results after which amendments and clarification of the legislation may be requested.
\end{abstract}

\section{UITTREKSEL}

In hierdie artikel word die wetlike beperking in die praktyk van die primêre gesondheidsverpleegkundige in die Republiek van Suid-Afrika, wat direkte implikasies het vir die bereiking van die doelwit: "Gesondheid vir almal teen die jaar 2000", verken en beskryf. Die vrae wat in hierdie navorsing beantwoord is, hou verband met wetlike beperkinge wat die praktyk van die primêre gesondheidsverpleegkundige obstrukteer. 'n Wetlike ontleding (dokumentanalise) is uitgevoer en sekere wetlike beperkinge is bevestig. Daar word aanbeveel dat 'n empiriese ondersoek gedoen word om die resultate te verifieer, waarna wetswysigings en uitklarings versoek sal word.

\section{INTROIDUCTION}

State registration for nurses, which is authorisation or legal sanctioning by the State for the practice of a profession, is more than one hundred years old. The concept of State approval is an old one and dates back to the time of the pharaohs. Later during Roman and Anglo-Saxon rule, the guild movement came into being. A guild, which consisted of a group of people who practised a specific skill, came together and applied for Royal sanctioning of their trade. This same approach was used in the 19th century by doctors and nurses (Searle, 1991:3).

The guilds exercised control over the standards of a product or service rendered, determined the position or status of the group in society and maintained a strict ethical code to engender trust in their numbers and ensure the safety of the consumer; an analogy can be drawn to the profession of nursing and the early guild movement.

The registered primary health care nurse (PHCN) is legally authorised to practice nursing in terms of the Nursing Act (South
Africa, 1978, as amended). All other health care professionals are authorised to practice their profession in terms of their specific legislation and the PIIC service likewise is regulated by appropriate legislation.

The nature of nursing always has been dynamic and nurses traditionally had to fill gaps when other members of the multi-professional team were unavailable. This has led to a number of grey areas in practice. There were very few doctors or hospital facilities in the early days at the Cape and the social isolation and self-reliance of the people meant that care of the sick took place at home. This was a blend of medical practice and nursing care and encompassed many of the principles of comprehensive heal th care as we know it today. It had the welfare of individuals, families and communities at heart.

The development of nursing is linked to a tradition of medical practice and the history of nursing is closely interwoven with certain medical events. The growth of nursing and the growth of hospitals have a reciprocal relationship.

\section{IIEALTII MANPOWER}

An analyses of health manpower to determine availability and utilisation indicated that the nurse was the most available in terms of both distribution and numbers, in urban as well as rural communities. There were 67894 registered nurses, 28047 enrolled nurses and 44519 enrolled nursing assistants (presently defined as nurse auxiliaries) on the registers and rolls of the South African Nursing Council on the 31st of December 1991 (South African Nursing Council, 1992).

Nursing manpower constitutes $67,8 \%$ of the total health manpower in the Republic of South Africa - the balance is made up of $11,9 \%$ medical practitioners, $4,5 \%$ pharmacists, $2,0 \%$ dentists and $13,9 \%$ supplementary health professionals. The World Health Organisation's norm for registered nurses to population is 1:500. A realistic ratio of registered nurses to population in the Republic of South Africa, as recommended in the Mount Grace Report (Department of National Health and Population Development, 1990), is 1:416. The primary health care nurse thus has a vital and important role to play in the health services in the Republic of South Africa. The maldistribution of health manpower in the country with specific reference in this study to nurses, medical practitioners and pharmacists, places an even greater responsibility on the available nursing manpower and especially the primary health care nurse.

The primary health care nurse, in many cases, has not been able to affect the infant mortality rate because she may not prescribe medicine unless authorised thereto in terms of Section $38 \mathrm{~A}$ of the Nursing Act, 1978 (South Africa, 1978 , as amended). To comply with the National Health Mission and to meet the National Health Goals (Department of National Health and Population Development, 1992:3-5), the primary health care nurse has a dynamic role to play but has not made a significant impact on the Population Development Programme indicators, in spite of a broad scope of practice, clinical skills and comprehensive curriculum for basic training. The nurse is the most available of all health manpower and plays a key role as co-ordinator of the health team as an independent accountable practitioner. The medical practitioner has no clearly defined scope of practice as this has developed mainly through common law and ethical rules which provide 
Figure 1. A visual presentation of the relationship between the primary health care nurse and the other role-players in the delivery of a comprehensive health care service

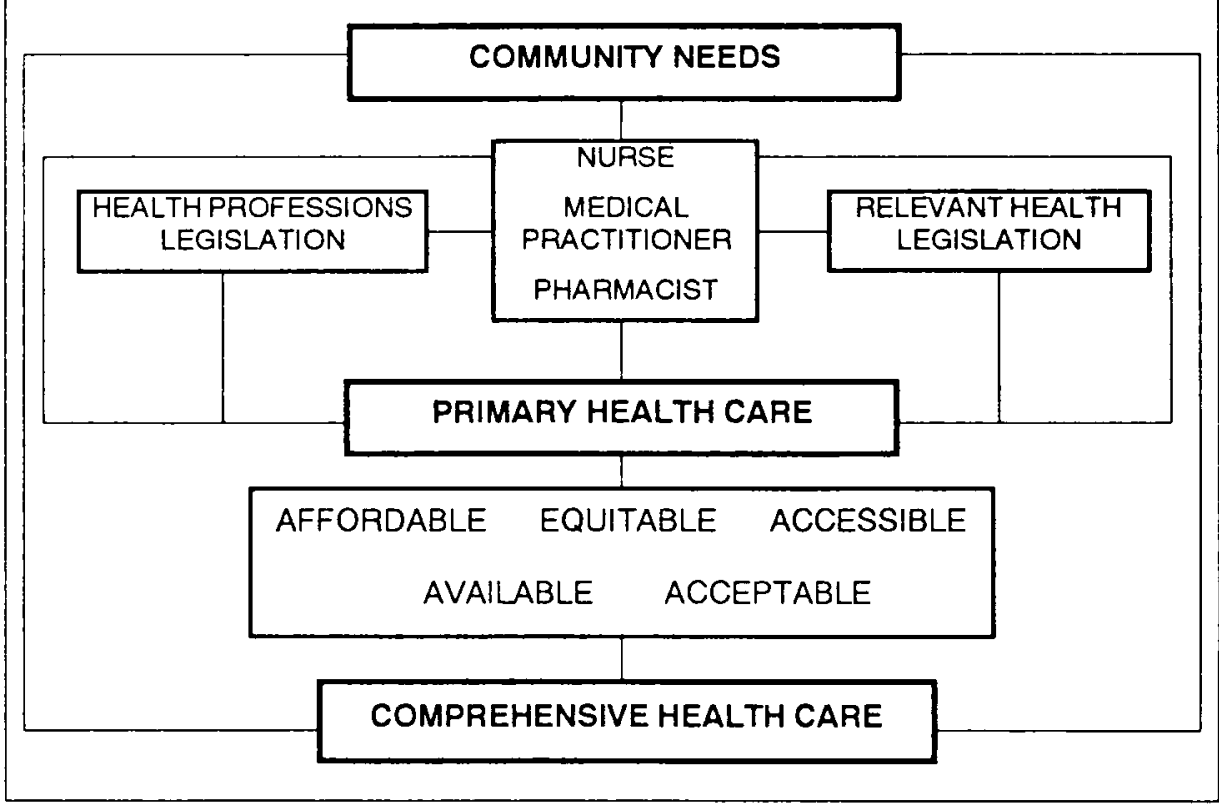

certain parameters (Strauss, 1984). Furthermore, the interpretation by the primary health care nurse of her scope of practice, tends to restrict rather than enable her to be more effective in primary health care services. To compound the problem there appears to be a great deal of ignorance with respect to the enabling ethico-legal framework which governs her practice.

\section{PROFESSIONAL LEGISI ATION}

The purpose of professional legislation is to delineate the area of practice of one professional group from other professional groups and to protect which belongs uniquely to that profession. The essence of professional development is control of the profession, by the profession, under Act of Parliament in the interests of the public good (Searle, 1988:76). The advantage of such an Act is that by legislation the profession is entrusted with the welfare of the public and this achieves status; only a profession which can be trusted with such a responsibility and is seen to be accountable for its actions, will gain such recognition (Searle, 1988:77). Professional legislationattempts to protect both the practice of the professional as well as the title of the profession.

The provisions contained in the Medical and Pharmacy Act, 1928, (South Africa, 1928) did not exclude nurses from diagnosing, prescribing and treating but probably never acted thus except to a limited extent as such need arose much later. As the community needs for primary health care increased, the demographic profile in the Republic of South Africa changed to emphasise the necessity for preventive health and a discrepancy appeared in the distribution of health manpower; the need arose then for the nurse to perform certain functions which usually fall within the scope of practice of the medical practitioner and pharmacist, when such workers are not available. The publication of the Medicines and Related Substances Control Act, 1965 (South Africa, 1965) limited the nurse in terms of the handling of medicine for the first time. Ironically this legislation occurred at exactly the time when more enablement of the registered nurse was required. Nurses in the Republic of South Africa are accountable for their practice and make a unique contribution to health services, but perhaps they need to examine closely legal and other restrictions which prevent them from making an even more significant contribution to "Health for all by the year $2000 "$.

\section{RESEARCH PROBLEM}

The researcher, as a health manager in the post of Chief Nursing Service Manager appointed to the Sub-directorate: Matters Relating the Heal th Professions, in the Chief Directorate: Advanced Health Care in the Department of National Health and Population Development, has as part of her function, discussions with members of all the health professions, including nurses, medical practitioners and pharmacists. She previously was also a professional officer with the South African Nursing Council, and during this period, whilst carrying out inspections at colleges and schools of nursing, became aware of the frustration of primary heal th care nurses at the limitations in health professions' legislation and other relevant legislation which directly influences their practice and prevents their optimum function. It seems, too, that nursing legislation is not correctly interpreted. The South African Nursing Association has confirmed this impression. (South African Nursing Association, 1989). The following research question is posed:- What are the legal limitations in the practice of the primary health care nurse and what is the nature and scope of these limitations?

The objective of this research is to perform a document analysis of selected health professions' legislation and other relevant health legislation and to identify the nature of the legal limitations in the practice of the primary health care nurse in the Republic of South Africa.

\section{DEFINITIONS}

\section{Primary health care nurse}

A primary health care nurse is a registered nurse and a person who has complied with the provisions of section 16 of the Nursing Act, 1978 , and who practises in a primary health care service in the Republic of South Africa.

\section{IIealth professions' legislation}

Heal th professions' legislation include those Acts of Parliament which delineate specific acts which fall exclusively within the domain of a particular health professional in the Republic of South Africa.

\section{Other health legislation}

Other health legislation refers to Medicines and Related Substances Control Act, 1965, as amended.

\section{Limitation}

Limitation is anything in legislation or the interpretation thereof which could hamper the effective functioning of the primary health care nurse in her practice.

\section{Republic of South Africa}

In this study the Republic of South Africa excludes the self-governing territories and those States which formally formed part of South Africa.

\section{RESEARCH DESIGN AND METHOD}

An exploratory descriptive study was undertaken in the Republic of South Africa's primary health care context. A document analysis of certain existing health professions' legislation and other relevant health legislation, was performed to determine the legal limitations in the practice of the primary health care nurse.

A content analysis was employed to identify legal limitations in the practice of the primary health care nurse. This is a method of studying and analysing legislation in a systematic and objective qualitative manner, according to the steps of Kerlinger (1986:477), namely:

- Deciding what the unit of analysis will be In this study the unit of analysis was the legislation.

- Borrowing or developing the set of 
categories. For this study it was the limitations in the practice of the primary health care nurse.

- Developing the rationale and illustrations to guide the coding of data into categories.

-.

- The main theme analysed was the legal limitation in the practice of the primary health care nurse.

The following sources were utilised in the content analysis for the purpose of literature control, namely dictionaries and legal textbooks for clarification of certain legal terms, as well as legal documents and legal concepts from the Department of National Health and Population Development. Any literature clarifying or interpreting the professional responsibility of the registered nurse in South Africa, was also utilised.

\section{Population}

The following legislation was analysed:

- The Nursing Act, 1978;

- The Pharmacy Act, 1974;

- The Medical, Dental and Supplementary Heal th Service Professions Act, 1974;

- The Medicines and Related Substances Control Amendment Act, 1991;

- The Medicines and Related Substances Control Act, 1965.

\section{Reliability and validity}

Due to the abstract nature of legislation the researcher's position had no effect on the research. The choice of legislation could have been based on only that which gave the desired response. In this study all relevant health legislation was included. Two independent researchers - one being a registered nurse, known for her legislative and professional-ethical nursing knowledge, and the other a health care legislation consultant at the Department of National Health and Population Development - verified the results of the content/document analysis, to ensure reliability of this study. Methodological validity was ensured by using Kerlinger's (1986:477) method of content analysis.

\section{RESULTS OF THE DOCUMENT ANALYSIS}

The results of legislation analysed will be described separately.

\section{Nursing Act}

Section 45(1)(q) of the Nursing Act, 1978 (South Africa, 1978) makes provision for the Minister, on the recommendation of the South African Nursing Council, to make regulations relating to the scope of practice of the registered or enrolled persons and the conditions under which registered or enrolled persons may carry on their profession.

Regulations relating to the scope of practice of persons registered and enrolled under the Nursing Act, 1978, were published in Government Notice R2598 of 30 November 1984 (South African Nursing Council, 1984). Conditions under which a registered midwife may carry on her profession were first published in Govemment Notice R2488 of 20 October 1990 . Conditions in terms of which the registered nurse may carry on her profession have not been determined. However, certain of the provisions of the Rules relating to the Acts and Omissions in terms of which the South African Nursing Council (SANC) may take disciplinary steps, specified by the Minister in terms of section 35 of the Nursing Act, 1978 and published in Government Gazette R387 of 15 February 1985 (South African Nursing Council, 1985), may be interpreted as conditions rather than acts or omissions. An example of this is rule 8 , which specifies conditions in terms of which a nurse in private practice may advertise.

To define a scope of practice can be hazardous because technological advances and the dynamic nature of nursing bring about changes in practice impossible to accommodate in a list of procedures or tasks. To express the scope of practice of nursing in lists and procedures negates the real nature of nursing and considers the technical aspects only (Searle, 1986:172).

It is the registered nurse who in most health care settings, is available for twenty four hours a day and is thus ideally suited to co-ordinate the multi-professional health team, based on the health needs and problems of the patients. If the other members of the multi-professional team are not available, she needs to have the skills and discretionary ability to do either what needs to be done herself, or to make suitable referrals. To co-ordinate patient care necessitates her moving into the grey areas of practice of the nurse, medical practitioner and pharmacist.

The following definitions from the Scope of Practice regulations Government Notice R2598 of 30 November 1984 (South African Nursing Council, 1984) will be analysed as they have specific relevance to the functioning of the primary health care nurse, in terms of this study.

"Diagnosing shall mean the identification of, and discriminating between physical, psychological and social signs and symptoms in man ..." (SANC, 1984).

In the absence of a specific definition of a word in legislation, the word assumes its ordinary meaning. According to Shorter Oxford English Dictionary (Little, Fowler \& Carlson, 1968:500) diagnoses in a medical context mean "determination of the nature of a disease condition; identification of a disease by investigation of its symptoms and history."
The motivation for defining the word "diagnosing" in the Scope of Practice regulation, can be assumed to have been the avoidance of the nurse making what is perceived to be a medical diagnosis. This definition is, however, confusing in that it creates the perception that there are different kinds of diagnoses and that registered nurses and medical practitioners are busy with different actions.

Searle (1986:176) interprets as follows: "Registered nurses make a nursing diagnosis, not a medical diagnosis for the purpose of:- a) identifying nursing needs to plan nursing care or action b) identifying a medical need and hence a need for referral to a doctor or hospital." By implication the registered nurse under certain conditions, for example emergencies, may make a medical diagnosis, but in a primary health care setting she is limited to a nursing diagnosis. This severely limits the effective attainment of the mission of the National Primary Health Care Strategy (Department of National Health and Population Development, 1992).

"Prescribing shall mean giving the written directions regarding those treating, nursing care, co-ordinating, collaborating and patient advocacy functions essential to the effective execution and management of the nursing regimen" (SANC, 1984).

Prescribing of nursing care involves a thorough understanding of the prescriptions of the other members of the multi-professional team. The nurse needs to have a good knowledge of all the patho-physiological and pharmacological principles involved in the management of patient care in order to plan her own care. Under normal circumstances a nurse would not prescribe medical care but merely blend it into the nursing care, but if a medical practitioner or pharmacist is not available, she could and should, without "authorisation" prescribe medical care because her basic training should have equipped her to do so. The registered nurse remains accountable for her actions in terms of the Acts and Omissions in Govemment Notice R387 of 15 February 1985 (SANC, 1985).

The Oxford Dictionary (Little, Fowler \& Carlson, 1968:1573) defines prescribe as "in a medical context to advise, or order the use of a medicine, etc. with directions for the manner of using it." Clearly the intention of the South African Nursing Council was to limit the registered nurse to prescribing nursing care only and to prevent her transgression into the domain of the medical practitioner.
"Treatment shall mean selection and performance of those therapeutic measures essential to the effective execution and management of the nursing regimen" (SANC, 1984).

In primary health care settings a medical 
practitioner is not available in the same way as in a hospital. The unpredictable availability of medical practitioners in primary health care makes it imperative that the nurse initiate medical treatment in a variety of diseases which are of local, regional or national importance, for example Tuberculosis, Sexually Transmitted Diseases, etc. (Department of National Health and Population Development, 1991:10). Diseas such as these have a direct impact on morbidity and mortality rates in South Africa.

\section{The Pharnacy Act, 1974}

The provisions of the Pharmacy Act, 1974 (South Africa, 1974b) Section 29, relevant to the functioning of the primary health care nurse, are the following:

"(1) Subject to the provisions of subsection (3) any person who, not being registered as a pharmacist -

(a) for gain practises as a pharmacist, or carries on business as a pharmacist or for gain performs any act specially pertaining to the profession of a pharmacist; ... shall be guilty of an offence ...

(2) The following act shall, for the purposes of subsection (1) be deemed to be acts specially pertaining to the profession of a pharmacist -

(d) the furnishing of advice to any person with regard to any medicine supplied to him.

(3) The provisions of subsections (1) and (2) shall not prohibit -

(e) the keeping of medicines and its supply to patients in hospitals or other institutions for the treatment of sick persons, under the direction of a medical practitioner and in accordance with the provisions of the Medicines and Related Substances Control Act, 1965, by any person registered or enrolled under the Nursing Act, 1957 (Act no 69 of 1957)

(f) the keeping of medicines and its supply by any persons or organization performing a health service and authorized in writing by the Secretary for Health acting after consultation with the council, to acquire medicines for the performance of such service."

With reference to the functioning of the nurse in a primary health care setting, section 29 limits her functioning in that she needs a medical practitioner to prescribe medication for a patient. Section $29(3)$ (e) allows the nurse to keep medicine and supply it to patients, under the direction of a medical practitioner. Section $29(f)$ refers to the keeping of medicines by a person or organisation in terms of the provisions of the Medicines and Related Substances Control Act, 1965 (South Africa, 1965 ) in terms of section 22A(12): a nurse, however, only may supply medicine to the patient on the prescription of a medical practitioner. This severely limits the functioning the primary health care nurse, because the medical practitioner in many instances is only available for a limited time. The reason why the organisation rendering a health service and the registered nurse in its employ, is issued with a permit is because a pharmacist or medical practitioner is not readily available.

The pharmacist's training is primarily in pharmacology and pharmacodynamics during his basic training with no preparation in the physical and psychological assessment of patients. The latter is part of the basic nursing curriculum.

Section 292(d) with respect to the "furnishing of advice to any person with regard to any medicine supplied by him" and section 29 3(e) place limitations on the practice of the primary health care nurse, a large part of whose practice is based on health education including advice to patients on medications (Department National Health and Population Development, 1992:12)

Medical, Dental and supplementary Health Service Professions Act, 1974

The provisions of the Medical, Dental and Supplementary Health Service Professions Act (South Africa, 1974b), section 36(1)(b) are as follows:

"(1) Subject to the provisions of subsections (2) and (3) and section 37, any person, not registered as a medical practitioner or as an intern, who -

(b) for gain

(i) physically examines any person

(ii) performs any act of diagnosing, treating or preventing any physical defect, illness or deficiency in respect of any person

(iii) advises such person on his physical state

(iv) on the ground of information provided by any person or obtained from him in any manner whatsoever

(aa) diagnose such a person's physical state

(bb) advises such a person on his physical state

(cc) supplies or sells to or prescribes for such a person any medicine or treatment (v) prescribes or provides any medicine, substance or thing, or

(vi) performs any other act specially pertaining to the profession of a medical practitioner."

The provisions of section 36 (1)(c) however are as follows:

"except in accordance with the provisions of the Public Health Act, 1919, the Nursing Act, the Chiropractors Act, and sections $32,33,34$ and 39 of this Act, performs any act whatsoever having as its object -

(i) the diagnosing, treating or preventing of any physical defect, illness or deficiency in any person ..."

The Nursing Act could make provision for conditions for the acts as set out in Section 36(1)(a) and (b). By defining the words diagnosing, treatment and prescribing, the Nursing Act (South Africa, 1978) is in fact confining the scope of what the nurse can do in a primary health care setting in terms of these professional responsibilities.

The Medical, Dental and Supplementary Health Service Professions Act (South Africa, 1974a) does not define the words diagnosis and treatment. The word prescribe is defined in a legal context, not a medical context, in the Act, thus relying on the dictionary definition of the word.

Steyn (1981:2) states with respect to the intention of the legislator, that the sovereign rule of all interpretations and a rule to which all other rules are subservient, is the following: " ... dat indien dit maar een maal vassstaan wat die werklike bedoeling is wat die woorde wil uitdruk, aan daardie bedoeling gevolg gegee moet word." The meaning of a word is therefore that what it was intended to mean by the person describing the word

Historically there has been no need to question the role of the registered nurse or pharmacist where it dovetails with that of the medical practitioner. Professions are dynamic and change and develop in relation to the needs of individuals and communities and grey areas of practice (which have always existed) have become more pronounced. The traditional interpretation of heal th professions legislation and perception of the medical practitioner, registered nurse and pharmacist of each other's roles, is now limiting the provision of basic health care in South Africa as envisioned in the primary health care strategy (Department of National Health and Population Development, 1992:4).

The provision of an Act only goes as far as its words, and the expositor of the law must occupy himself with the same things contained in the law. The role of the expositor of the law is to determine the thought content of the legislator. The expositor of the law is reliant 
on the words used by the legislator, to enable him to determine the thought content. No matter how carefully words are chosen, there is difficulty in selecting language which will on the face of it express generally the idea, but will not, when applied under certain circumstances go beyond it and when applied under other circumstances, fall short of it (Steyn, 1981:1)

\section{The Medicines and Related Substances Control Act, 1965}

Since the inception of this Act and the Medicines Control Council in 1965, there has been a dilemma of deciding to what extent the Medicines and Related Substances Act (South Africa, 1965) can limit the practice of the various health professionals. The question may well be asked whether the limitation in terms of the use of certain medicines by health professionals, is determined from the perspective of the inherent hazardous nature of medicine and the potential for abuse, rather than the needs of individuals for that medicine and the availability of the appropriate category of health worker to administer it. Should this be so, it has contributed to the de facto situation where the doctor merely acts as a figurehead signing prescriptions after treatment has been initiated by the registered nurse.

The Medicines and Related Substances Act (South Africa, 1965) section 22 (12(A) determines as follows: "Notwithstanding the other provisions of this section, the Director-General may, after consul tation with the South African Pharmacy Council, issue a permit to any person or organization providing a heal th service, authorizing such a person or organization to acquire, possess, use or supply any specified Schedule one, Schedule two, Schedule three or Schedule four substance, and such permit shall be subject to such conditions as the Director-General may determine." The other provisions of this section describe fully the control of medicines and scheduled substances. The professional groups concerned with the "sale" of medicines are the medical practitioner, dentist, pharmacist and veterinarian.

"After consultation with the Pharmacy Council" means acknowledgement of, not requiring sanction or permission from the Council. Under "sell" is understood to sell by wholesale or retail and include import, offer, advertise, keep, expose, transmit, co-sign, convey or deliver for sale or authorise, direct or allow a sale or prepare or possess for purpose of sale, and barter or exchange or supply or dispose of to any person whether for a consideration or otherwise. "Sale" and "sold" have corresponding meanings.

The control of medicines and scheduled substances is therefore entrusted to a limited group of persons. In some aspects of a health service in the private sector, however, a gap exists when members of this group cannot be present when rendering this service. Special authority must then be bestowed upon an organisation to handle medicines in these special circumstances. A permit under section $22 \mathrm{~A} \mathrm{(12)} \mathrm{of} \mathrm{the} \mathrm{above-mentioned} \mathrm{Act}$ therefore is issued under certain conditions.

Conditions in accordance with the Act were drawn up by the Directorate, Pharmaceutical Services of the Department of National Heal th and Population Development, in consultation with the South African Pharmacy Council. The Act does not, however, provide for consultation with the Pharmacy Council in relation to the conditions prescribed, but only with the actual issue of the permit to any person or organisation. In terms of the conditions which were determined initially. it is the medical practitioner who is responsible for the control of the medicine, and not the person or organisation to whom the permit is issued. This is ultra vires the Medicines and Related Substances Control Act (South Africa, 1965).

Subsection 12 of section 22 also authorises the holder of a permit the privilege to acquire, possess, use and supply certain medicines. The medical practitioner, however, still remains responsible for the treatment of the patient and therefore also for the prescribing of medicines. It is confirmed by the signature of the medical practitioner on all prescriptions: "It must be emphasised that the medical practitioner is, at all times, finally responsible for the control and running of the clinic, and will be regarded as such by the Department" (Department of National Health and Population Development, 1985:3).

It is unrealistic and in fact ultra vires the Act to hold the medical practitioner responsible for patients when he is very often only available for one hour per week. The running of the primary health care clinic and the responsibility for the medicine in the clinic rests with the registered primary health care nurse, who according to the prescribed conditions, must be in full-time service with the organisation (Department of National Health and Population Development, 1985:4).

The permit makes provision for Schedule one to Schedule four medicines only. Unscheduled medicines may be kept. If a medical practitioner wishes to prescribe Schedule five to Schedule seven medicines, the registered nurse may not handle them. They may be handled by the medical practitioner only and no other person may have access to such medicines.

This in fact means that the patients on treatment, which include schedule five medicine, cannot be monitored and treatment supervised by the nurse and this thus leads to a loss of manhours and a resultant economic loss to the employer. This negates the very essence of a primary health care service.

During discussions which took place in March 1992 between the South African Nursing Association, the Medicines Control Council and legal advisory section of the Chief Directorate: Advanced Health Care and the Director-General of the Department of National I Iealth and Population Development, it was agreed that the departmental interpretation of the Act needs review and the formulation of new conditions. The regulations in terms of the new section 22(4), as envisaged in the Medicines and Related Substances Control Amendment Act (South Africa, 1991) when promulgated, will repeal section $22 \mathrm{~A}(2)$ and thus obviate the need for permits (Bierman, 1992).

\section{CONCLUSIONS AND RECOMMENDATIONS}

Following the analysis of the legislation, limitations in the practice of the registered primary health care nurse were found in the letter of the law, but many limitations which by interpretation have become entrenched in the practice of the registered primary health care nurses, were also found. The following legislative limitations were found to exist:

- The Medical, Dental and Supplementary Health Professions Act (South Africa, 1974a) section $36(1)(b)$ and (c) with respect to the physical examination and diagnosing of a patient and prescribing of medical treatment.

- The Pharmacy Act (South Africa, 1974b), section 29(2)(d) and (e) with respect to advice about medication and the limitation of the supply of medicine to patients in hospital.

- The Nursing Act (South Africa, 1978) section $38 \mathrm{~A}$, with respect to the limitations on registered nurses in certain primary health care areas. Government Notice R2598 of 30 November 1984 (SANC, 1984), which describes the scope of practice of the registered nurse and defines diagnoses, prescribing and treatment.

- The Medicines and Related Substances Control Act (South Africa, 1965) section 22A(12), in terms of which conditions are prescribed which limit the primary health care nurse in her practice.

The fact that the analysis of the legislation was done by the researcher who is not a legal expert may have been limiting to the study. These interpretations however, were, verified by the independent researchers.

It is recommended that an empirical investigation be done by means of interviews with primary health care practitioners (medical and nursing) to verify these findings and to ascertain their views on legislative limitations in primary health care nursing practice. Further recommendations to deregulate the professional practice of the primary health care nurse will be made, based on the verification results. The registered primary health care nurse needs to act in the interest of the patient. Her practice is, 
however, limited by legislative regulation which needs review.

\section{REFERENCES}

BIERMAN, JK (1992): Interview on 23 March 1992 with Miss OH Muller in Pretoria, in connection with the issuing of permits in terms of section $22 \mathrm{~A}(12)$ of the Medicines and Related Substances Control Act, no. 101 of 1965

DEPARTMENT OF NATIONAL HEALTH AND POPULATION DEVELOPMENT (DNHPD), (1985): Conditions for supplying permits to occupational health nurses. Pretoria: Department of National Health and Population Development.

DEPARTMENT OF NATIONAL HEALTH AND POPULATION DEVELOPMENT (1990): Mount Grace Report. Pretoria: DNHPD.

DEPARTMENT OF NATIONAL HEALTH AND POPULATION DEVELOPMENT, (1991): The population development programme in South Africa and the role of the Chief Directorate: Population Development. Pretoria: DNHPD.

DEPARTMENT OF NATIONAL HEALTH AND POPULATION DEVELOPMENT, (1992): Strategy for primary health care in South Africa. Pretoria: DNHPD.

KERLINGER, $F$ (1986): Foundations of behavioral research. New York: Holt, Rinehart \& Winston.

LITTLE, W; FOWLER, HWJ \& CARLSON, J (1968): The shorter Oxford English Dictionary on historical principles, Volume 1 and 11; third edition. Oxford: Clarendon.

MUNHILL, PL \& OILER, CJ (1986): Nursing Research: a qualitative perspective. Connecticut: Butterworths.
SEARLE, C (1986): Professional practice: a South African nursing perspective. Durban: Butterworths.

SEARLE, C (1988): Aspects of selected nursing issues. Durban: Butterworths

SEARLE, C (1991): Die strewe na voortreflikheid: die eeufees van staatsregistrasie vir verpleegkundiges en vroedvroue in Suid-Afrika 1891-1991. Durban: Butterworths.

SOUTH AFRICAN NURSING ASSOCIATION, (1989): Report on a pilot study on the interpretation by nurses of nursing legislation. Pretoria: SANA

SOUTH AFRICAN NURSING ASSOCIATION, (1991): Position paper: ethical standards for nurse researchers. Pretoria: SANA.

SOUTH AFRICAN NURSING COUNCIL, (1984): R2598, as amended. Regulations relating to the scope of practice of persons who are registered or enrolled under the Nursing Act, 1978. Pretoria: Govemment Printer.

SOUTH AFRICAN NURSING COUNCIL, (1985): R387, as amended. Rules setting out the acts or omissions in respect of which the council may take disciplinary steps. Pretoria: Government Printer.

SOUTH AFRICAN NURSING COUNCIL, (1990): Primary health care - South African Nursing Council (SANC) viewpoint. Pretoria: SANC.

SOUTH AFRICAN NURSING COUNCIL (SANC), (1992): Statistics for the calender year 1991. Pretoria: SANC.

SOUTH AFRICA, (1928): Medical, Dental and Pharmacy Act, 1928, Act no. 13 of 1928. Pretoria: Government Printer.
SOUTH AFRICA (Republic), (1974a) Medical, Dental and Supplementary Health Service Professions Act, 1974, Act no. 56 of 1974 . Pretoria: Government Printer.

SOUTH AFRICA (Republic), (1974b): The Pharmacy Act, 1974, Act 53 of 1974. Pretoria: Government Printer.

SOUTH AFRICA (Republic), (1978): The Nursing Act, 1978, Act no. 50 of 1978 Pretoria: Government Printer.

SOUTH AFRICA (Republic), (1991): The Medicines and Related Substances Control Amendment Act, 1991, Act no. 94 of 1991 Pretoria: Government Printer.

STEYN, LC (1981): Die uitleg van wette; vyfde uitgawe. Johannesburg: Juta.

STRAUSS, SA (1984): Doctor, patient and the law: a selection of practical issues second edition. Cape Town: van Schaik.

WOODS, NF \& CATANZARO, M (1988) Nursing Research: theory and practice. St Louis: Mosby

WORLD HEALTH ORGANIZATION, (1978): Alma Ata 1978; Primary Health Care. Geneva: World Health Organization.

\begin{tabular}{|} 
Jo Bierman \\
M.Cur. student \\
Rand Afrikaans University \\
Marie Muller \\
D.Cur. (RAU) \\
Professor: Nursing Department \\
Rand Afrikaans University \\
\hline
\end{tabular}

